\title{
University Governance and Leadership in Continental Northwestern Europe
}

Harry de Boer (University of Twente, the Netherlands)

Peter Maassen (University of Oslo, Norway) ${ }^{1}$

\begin{abstract}
With regard to the governance structures of European universities, various governmental reforms have been initiated aimed at changing their democratic nature, the composition of governing bodies, and the degree of centralization in decision-making. In addition, these reforms made an effort to redirect the balance between collective and individual governing responsibilities (Gornitzka et al. 2017). In this article, we address the effects of such governance reforms in public, comprehensive universities in the Netherlands and Norway. Differences across countries, even within a relatively homogeneous region such as Northwestern Europe, can be traced back to differences in underlying political visions towards university governance (Olsen 2007; Christensen et al. 2014). After an overview of the main features of university governance structures in the two countries, we argue that a specific regional university governance practice has emerged with different combinations of executive and democratic elements.
\end{abstract}

Keyword Governance reform; University governance structures; Norway; the Netherlands; University decision-making

\section{Introduction}

Over the last decades, various national reforms were initiated in Europe aimed at enhancing the relevance and productivity of higher education. The underlying reform agendas have many elements in common (Gornitzka and Maassen 2014), which are argued to represent key New Public Management (NPM) ideas (Bleiklie 1998; Enders et al. 2013). However, these NPM interpretations are rather broad and too general for doing justice to important inter-country differences in how reforms affected university governance modes, funding mechanisms and organisational features. In this article, we will discuss the effects of the reforms in the area of institutional governance structures in public, comprehensive universities in Continental Northwestern Europe. Our analytical starting-point is that globally various fundamentally different university governance and leadership models can be identified. The variations in how these models are used in practice can be traced back to differences in underlying political visions towards university governance (Olsen 2007; Christensen et al. 2014). Consequently, even within a relatively homogeneous region, such as Continental Northwestern Europe, there are important variations in reform effects (Hall and Soskice 2001). We have selected two national cases, the Netherlands and Norway, for discussing the nature of these variations. The rationale for this selection is that the two countries represent two different reform approaches in their region, with the Netherlands seemingly moving more in the direction of the Anglo-Saxon university approach, with Norway remaining relatively strongly embedded in the Nordic university governance traditions (Maassen et al. 2011).

\footnotetext{
${ }^{1}$ Corresponding author
} 
First, an analytical framework will be presented, followed by a brief overview of the main features of university governance structures in the Netherlands and Norway. For the comparative analysis of the two countries, four dimensions are used: 1) the internal democratic nature of the governance structure; 2 ) the external involvement in university governance; 3 ) the level of centralisation of decision-making authority in the university; and 4) the balance between collective and individual governance responsibility.

\section{Analytical framework}

Our analytical approach builds on two theoretical traditions anchored in institutional theory that conceptualize the 'filtering' of generic public sector reform models (cf. Pollitt 2005; Greenwood et al. 2017). We argue first that the implementation of global reform agendas is subject to national filters, implying that there are differences among national systems in how governance reforms are enacted. Second, we argue that universities form a specific institutional sphere that has created throughout its long history a sector specific filter for handling external pressures to functional adaptation (March and Olsen 1989; Olsen 2007; Gornitzka et al. 2017, 275). These two types of filters are of relevance for interpreting the differences in reform effects among countries and among universities as well as the gaps between the intentions of the reform agendas and the changes in governance structures that are realised within universities.

For interpreting the effects of national filters Olsen's classification $(2007,30)$ of four visions of university organisation and governance is relevant. These four visions are first the university as a rule-governed community of scholars; second, the university as an instrument for realizing national political agendas; third, the university as a representative democracy; and fourth, the university as a service enterprise embedded in competitive markets. Gornitzka (2020) has used this classification for conceptualising how these visions affect specific key features of university governance, leading to important variations among countries (see table 1).

Table 1: Four visions on university governance and its main aspects

\begin{tabular}{|c|c|c|c|c|}
\hline $\begin{array}{l}\begin{array}{r}\text { Vision on } \\
\text { university } \\
\text { governance }\end{array} \\
\text { University } \\
\text { governance } \\
\text { aspects }\end{array}$ & $\begin{array}{l}\text { Norm-steered } \\
\text { academic } \\
\text { community } \\
\text { (“Republic of } \\
\text { Science”) }\end{array}$ & $\begin{array}{l}\text { Instrument for } \\
\text { national } \\
\text { authorities }\end{array}$ & $\begin{array}{c}\text { Representative } \\
\text { democracy } \\
\text { (negotiation } \\
\text { based) }\end{array}$ & $\begin{array}{c}\text { Service company } \\
\text { in a competitive } \\
\text { market setting }\end{array}$ \\
\hline $\begin{array}{l}\text { Role governance } \\
\text { actors and bodies }\end{array}$ & $\begin{array}{c}\text { Minimal } \\
\text { governance }\end{array}$ & $\begin{array}{c}\text { Link between state } \\
\text { authorities and } \\
\text { university }\end{array}$ & $\begin{array}{c}\text { Arena for internal } \\
\text { (and external) } \\
\text { interests }\end{array}$ & $\begin{array}{c}\text { Assure } \\
\text { economically } \\
\text { defendable } \\
\text { management; } \\
\text { strategic decisions } \\
\text { about profile and } \\
\text { niche }\end{array}$ \\
\hline Leadership role & $\begin{array}{l}\text { Elected primus } \\
\text { inter pares }\end{array}$ & $\begin{array}{l}\text { Rules / procedures } \\
\text { manager }\end{array}$ & $\begin{array}{l}\text { Politician / } \\
\text { negotiator }\end{array}$ & CEO / unit manager \\
\hline Authority through & $\begin{array}{c}\text { Academic } \\
\text { competence and } \\
\text { status }\end{array}$ & $\begin{array}{c}\text { Formal positional } \\
\text { authority }\end{array}$ & $\begin{array}{l}\text { Resources / } \\
\text { networks }\end{array}$ & $\begin{array}{l}\text { Professional } \\
\text { leadership } \\
\text { authority }\end{array}$ \\
\hline
\end{tabular}




\begin{tabular}{|l|c|c|c|c|}
\hline Role of the state & $\begin{array}{c}\text { Patron and } \\
\text { protector of } \\
\text { institutional sphere }\end{array}$ & $\begin{array}{c}\text { "Principal" \& } \\
\text { regulator; control } \\
\text { over university } \\
\text { governance bodies } \\
\text { and actors }\end{array}$ & $\begin{array}{c}\text { Negotiation } \\
\text { partner }\end{array}$ & $\begin{array}{c}\text { Facilitator of well- } \\
\text { functioning market }\end{array}$ \\
\hline $\begin{array}{l}\text { Rationale for } \\
\text { university } \\
\text { autonomy }\end{array}$ & $\begin{array}{c}\text { The university as a } \\
\text { value embedded } \\
\text { institution }\end{array}$ & $\begin{array}{c}\text { The university as a } \\
\text { link in a } \\
\text { hierarchical } \\
\text { delegation chain }\end{array}$ & $\begin{array}{c}\text { Mixed - } \\
\text { Co-determination } \\
\text { and interest } \\
\text { representation }\end{array}$ & $\begin{array}{c}\text { The university has } \\
\text { to be 'set free' for } \\
\text { being able to } \\
\text { operate in a } \\
\text { market setting }\end{array}$ \\
\hline
\end{tabular}

Source: based on Gornitzka, (2020; adapted from Olsen, 2007, 30)

From the late 1960s to the late 1990s, European governments emphasised ideas from the visions of the university as a norm-steered academic community and the university as a representative democracy in their university governance approach (de Boer and Stensaker 2007). Recently, the balance has shifted with the vision of the university as a service company having become more prominent in university governance modes. Moreover, there was a growing interest in the role of universities for the economy, leading to an increasing incorporation of the vision of the university as an instrument for achieving national economic objectives. Consequently, university reform agendas proposed the following changes (Gornitzka et al. 2017):

1. Democratic nature of the formal governance structures. Reform agendas promoted the introduction of executive university boards as main decision-making bodies thereby either abolishing democratic councils, or radically changing their mandate from decision-making to advisory. In addition, the agendas argued for appointed instead of elected university leaders.

2. Formal external involvement in university governance. The formal inclusion of external representatives in university governance, at all relevant levels and in all relevant boards and other bodies was promoted.

3. Level of centralisation of formal decision-making powers within universities. In response to the problem of fragmented, incoherent university decision-making, reform agendas proposed the introduction of strong, professional leadership for developing the university into an integrated, strategic organisational actor (Krücken and Meier 2006).

4. Balance between collective and individual governance responsibility. The lack of personal responsibility and commitment in university governance was deemed to be problematic. Therefore, reform agendas promoted to shift decision-making power from collective bodies to individual leaders.

We will discuss the extent to which these four proposed changes have been realised in the Netherlands and Norway. We will first present an overview of some key characteristics of the current university governance structures in the two countries.

\section{Dutch university governance structures}

At the end of the 1990s, the governance model of Dutch universities changed drastically. In 1997, a new university governance law was passed by Parliament, which put an end to the system of democratic co-determination in all strategic areas among the formal university leadership body and representative councils (Enders et al. 2013). Nearly all responsibilities regarding both academic and 
non-academic matters were from then on formally concentrated in executive boards at central and faculty level. The representative bodies were retained, but lost many of their formal responsibilities. Moreover, a new governing body - Raad van Toezicht (in English supervisory board) - was introduced. Consequently, the main governing bodies of the current Dutch university governance structure currently are the supervisory board, the executive board and the Universiteitsraad (in English: university council'2). In addition, there is a board for promotions (also known as 'board of deans') and trade union representative bodies ('local consultation'), while universities can also have various other central advisory councils and committees. We concentrate here on the main three governance bodies.

The supervisory board consists of five external members, all appointed for four years by the Ministry of Education, Culture and Science. This board has a threefold task. Firstly, it is the employer of the university's executive board and appoints, suspends and dismisses the executive board's members, including the rector. Secondly, it supervises the performance of activities and the exercise of authority by the executive board. Thirdly, it advices the executive board. The supervisory body is accountable to the Minister and obliged to provide information to the Minister on request. Since 1 January 2014, the Minister has the authority to issue an instruction to the supervisory board in the event of mismanagement, e.g. financial mismanagement or serious negligence as regards the quality of education. The executive board members attend the supervisory board's meetings in an advisory capacity, unless the supervisory board decides otherwise. The meetings and documents of the supervisory board are not public. The same applies to the meetings and documents of the executive board.

The executive board ${ }^{3}$ is charged with the day-to-day administration and management of the university as a whole. It acts as a 'collegium' and is (ultimately) responsible for key governance areas, such as the university strategy, its development plan and budget, the quality of education and research, human resources management, property issues, legal transactions, and approval of faculty regulations. In addition, the executive board is also responsible for the appointment, suspension and dismissal of the faculty deans. The executive board is accountable to the supervisory board and provides the supervisory board with all required and requested information. The executive board depends on the supervisory board's approval in certain cases, and must also seek advice from the university council or get its consent for certain matters.

The university council represents the interests of all staff members and students towards the university's executive board. As a permanent advisory and discussion partner of the executive board, the university council is contributing to university policy-making and its day-to-day operations. The university council may issue solicited and unsolicited advice to the executive board on matters considered to be of interest to the university. In terms of solicited advice, the executive board has to consult the university council in key governance areas, such as the university budget, personnel and appointment policies, institutional tuition fees, and health and safety policies. In addition, the university council has the right of consent in certain areas, for instance, the strategic institutional plan, the model of quality assurance, the student statute, the internal governance regulations, and basic principles of the annual budget. In contrast to the supervisory board and the executive board, the university council's meetings and documents are public. The size of the university council varies per university. The largest university council has twenty-four members, the smallest sixteen. Its

\footnotetext{
${ }^{2}$ The translation of a University Council as 'representative advisory council' that is sometimes used is not correct because the council has more than just advisory rights.

${ }^{3}$ The executive board consists of three members, usually the rector, the president and a 'third member'. In a number of universities, the functions of rector and president are combined.
} 
composition is based on the principle of parity: half of the seats are for students, half for university employees. The term of office is two years for staff members and one year for students. The university council chooses its chair from among its members. The way in which the student and staff representatives are elected is laid down in electoral regulations that are determined by the executive board. The method of election differs per university.

By dividing responsibilities and tasks, rights and obligations between the supervisory board, the executive board and the university council, the national legislator aims at creating an effective system of checks and balances with countervailing powers. However, this does not alter the fact that the executive board should be seen as the central body in the governance structure. Finally, it is worth mentioning that besides this triangle, most universities have an (informal) management team, known under different names, where the executive board and deans meet. This consultative body is not stipulated in the law, but does play an important role in university decision-making.

\section{Norwegian university governance structures}

Following the Bologna Process the Norwegian government introduced the Quality Reform in Higher Education (2003/04), which was aimed at modernising the governance, organisation and funding of Norwegian higher education. One of its outcomes was a dramatic restructuring of the Norwegian higher education landscape: from four universities and twenty-six professional higher education institutions in 2003 to ten universities and seven (public) professional higher education institutions in 2020. In addition, it led to a new public funding mechanism for universities, which included a considerable performance component. The reform also introduced a new university governance structure, which in a number of respects integrated an executive dimension into the strong democratic foundation of intra-university governance. All universities are since 2003 required to have a university board and faculty boards, while they can decide themselves whether to have appointed or elected leaders at all three formal governance levels (central, faculty and departmental level). The two main governing bodies of the current university governance model are the university board and the body responsible for the day-to-day management (including the rector). In addition, Norwegian universities have a large number of informal councils and committees, which have an advisory role. Examples are education and research councils and committees that advice the university management in a large number of areas, such as equal opportunities, learning environments, research ethics, north-south relationships, and collaboration with the private sector. In addition, all universities have a platform where the management team meets with the deans. The two main bodies have the following characteristics and tasks.

The university board is the university's highest decision-making body. The board is responsible for ensuring that the institution maintains high academic standards, and is run efficiently and in accordance with current laws and rules. All strategic institutional decisions made by actors or bodies other than the board have to be made following delegation from the board, but remain its responsibility. The board's main tasks are to draw up the strategy for the university's educational and research activities and produce plans for its academic development. The board establishes goals and performance requirements and is responsible for ensuring that the university's financial resources and property are managed in accordance with the rules and regulations laid down by the public authorities. The board is also responsible to the university's administration and supervises its operations. Each university board consists of eleven members: four external members, three members representing the university's tenured academic staff, one member representing the university's temporary academic staff, one member representing the non-academic staff, and two 
student representatives. There is an important difference in composition between universities with an elected rector and universities with an appointed rector. An elected rector is member and chair of the university board. At universities with an elected rector he/she is regarded as one of the tenured staff members in the board, implying that in addition to the rector the board has two elected tenured staff representatives. The rector is elected by the whole university community through a weight votes system. This implies that the votes of the academic staff weigh more than the votes of the students and the non-academic staff. In the case of an appointed rector, he/she is not a member of the board and one of the external members acts as the board's chair. It also means that there are three elected tenured staff board members. The rector is appointed by the university board, and participates in the board meetings as the board's secretary, without voting rights. In both cases, two of the external members are appointed by the Ministry of Education and Research, while two external members are appointed by local or regional governments. All other board members are elected by the university population (staff and students).

Also with respect to the university's day-to-day management team, there are important differences between universities with an elected versus an appointed rector. Each appointed rector is responsible for academic and administrative affairs, and is leading the management team that is composed of one or more pro-and vice-rectors, as well as administrative leaders. Elected rectors on the other hand are formally only responsible for academic affairs, while in these cases a university director, appointed by the Ministry, is the head of the university administration. The management team consists next to the elected rector and the university director of a pro-rector, one or more vicerectors, and a deputy university director (or equivalent).

\section{Discussion}

The governance structures of Continental Northwestern European universities have changed in many respects. An important component in this is the shift from an emphasis on the interests of the academic staff, to the focus on the contributions of the university to socio-economic innovation and national economic growth. However, the nature of the actual changes are dependent on the working of national and institutional 'filters' (e.g. Greenwood et al., 2017). A number of different reform effects on institutional governance between the Dutch and Norwegian universities are summarised in table 2 .

Democratic nature of the formal governance structures. Overall, the reforms have affected the democratic nature of the university governance structure more at the Dutch than at the Norwegian universities. While in Dutch universities the staff and students are no longer directly represented in the central university executive governing bodies, in Norway university boards, as the highest decision-making authority, are composed of student and staff representatives as well as external members, without any of these groups having a majority in the board. In addition, the continuous authority of Norwegian universities to decide themselves whether they want to have elected or appointed leaders is an important democratic element compared to Dutch universities where all leaders have to be appointed. However, this does not mean that the Dutch university community does not play a role in executive appointments. For example, for the appointment of the executive board the supervisory board sets up an application committee, which also includes a student and a staff member from the university council. Appointments are based on public profiles and the university council is involved in drafting these. Further, prior to the appointment of an executive board member, the supervisory board must consult the university council. 
Further, the Dutch universities' executive boards are accountable not to the (democratic) university council, but to the institution's supervisory board, which is made up entirely of appointed external members. In addition, contrary to the Norwegian situation, the meetings and documents of the Dutch university executive and the supervisory board are not public.

The Norwegian reforms implied an integration of executive and democratic elements (in terms of university community representation) into one central governing board, while elements of formal staff and student representation are generally lacking at the central level of Dutch universities. At the same time, the powers of the university council as the main representative university body have definitely been strengthened over the past five years. Without questioning the dominant position of the supervisory and executive boards, it is incorrect to assume that the Dutch university community has no influence anymore in university governance matters.

Formal external involvement in university governance. In both countries formal external involvement in university governance has become a reality, but in different ways. The supervisory board of Dutch universities consists entirely of external members appointed by the minister. In addition, there is no obligation for the members of the executive board, including the rector, or deans to come from within the university. In practice, many leaders at Dutch universities were working elsewhere at the moment of their appointment. The university council members, on the other hand, all are from within the university and councils do not have outside members. At Norwegian universities, four of eleven members of the university board are external, appointed by the Ministry or local/regional authorities. All other members are internal. Also at Norwegian universities, there is no obligation that the academic leaders have to be internal. Nonetheless, most elected academic leaders, including the rector, are internal. In the case of appointed university leaders, it has been more common in Norway to recruit external candidates. In addition, the institutional administrative leaders are in general external and appointed by the Ministry, at the nomination of the university.

Level of centralization of formal decision-making powers within universities. At Dutch universities, the emphasis has shifted since 1997 to vertical governance relationships. This is reflected in the hierarchical way in which university leaders are appointed. In addition, changes in the manner in which the Ministry governs higher education, including stricter supervision, more attention to institutional profiling and 'new governance instruments', such as performance agreements, have strengthened the position of the central executive board. This implies that Dutch universities are more hierarchically organised and more centralised than Norwegian universities. While the university board in Norway is formally the highest executive body of the institution, overall decision-making authority in academic and administrative matters is divided over three levels: central, faculty and departmental. The faculty level functions as a linking pin between central and departmental level.

Balance between collective and individual governance responsibility. At Dutch universities, there has only been a partial shift towards individual responsibility. Dutch university governance has a long tradition of an executive body consisting of various persons, without individual leadership at central level. However, when the current governance model was introduced (1997), it was the explicit intention of the national legislator to introduce individual leadership at faculty level through a deanship with integral responsibilities. However, the legislator left some room to manoeuvre for each university in this matter, and most universities decided not to fully individualize faculty leadership. This implies that most Dutch university faculties have a leadership structure consisting of several members. At Norwegian universities, the emphasis in the central leadership structure has been less on a collective team than in the Netherlands. An appointed rector has the responsibility for administrative and academic affairs, while an elected rector has the responsibility for academic affairs, and through his/her position as board leader, also a strong say over administrative affairs. At 
the same time, because of the strong democratic and horizontal nature of the division of authority and accountability lines, individual leadership in Norwegian universities is within strong collective bodies and teams, instead of personal and hierarchical.

Table 2: Impact of reforms on selected Dutch and Norwegian university governance aspects

\begin{tabular}{|l|l|l|}
\hline Aspect & Dutch universities & Norwegian universities \\
\hline $\begin{array}{l}\text { Democratic nature of the formal } \\
\text { governance structures }\end{array}$ & $\begin{array}{l}\text { Dominance of appointed } \\
\text { leadership, decision-making not } \\
\text { fully transparent, vertical not } \\
\text { horizontal accountability }\end{array}$ & $\begin{array}{l}\text { Strong representation of the } \\
\text { university community (staff and } \\
\text { students) in the central university } \\
\text { board. Strong emphasis on } \\
\text { horizontal accountability. }\end{array}$ \\
\hline $\begin{array}{l}\text { Formal external involvement in } \\
\text { university governance }\end{array}$ & $\begin{array}{l}\text { External membership of } \\
\text { supervisory board; executives } \\
\text { frequently come from outside }\end{array}$ & $\begin{array}{l}\text { Four out of eleven university } \\
\text { board members external. Elected } \\
\text { academic leaders nearly always } \\
\text { internal candidates; appointed } \\
\text { leaders internal as well as } \\
\text { external; administrative leaders in } \\
\text { general external. }\end{array}$ \\
\hline $\begin{array}{l}\text { Level of centralization of formal } \\
\text { decision making powers }\end{array}$ & $\begin{array}{l}\text { Formally rather centralized, in } \\
\text { practice more participatory; } \\
\text { vertical system of leadership } \\
\text { appointments but with } \\
\text { involvement representative } \\
\text { bodies }\end{array}$ & $\begin{array}{l}\text { Formally rather decentralized } \\
\text { with emphasis on horizontal } \\
\text { accountability. }\end{array}$ \\
\hline $\begin{array}{l}\text { Balance between collective and } \\
\text { individual governance } \\
\text { responsibility }\end{array}$ & $\begin{array}{l}\text { Responsibility through collective } \\
\text { governing bodies }\end{array}$ & $\begin{array}{l}\text { Growing emphasis on individual } \\
\text { leadership at all levels, but still } \\
\text { strong collective orientation. }\end{array}$ \\
\hline
\end{tabular}

\section{Conclusion}

In the Netherlands and Norway, government-initiated reforms have affected the traditional democratic, academically oriented university governance structures. The resulting changes encompass comparable trends in the two countries when it comes to the professionalization of leadership, the introduction of executive boards, and direct external involvement in university governance, as well as a diminished involvement of the university community in strategic decisionmaking. At the same time, our analyses show that there are important differences between Dutch and Norwegian universities, which include a more direct continuation of democratic elements, and stronger horizontal and weaker hierarchical governance relationships in Norwegian than in Dutch universities, different compositions of the university decision-making boards, and slightly more emphasis on collective leadership in Dutch universities.

In many other European countries, comparable university governance reforms have been implemented (see, e.g., Carney 2006; Gornitzka et al. 2017; Hüther and Krücken 2018; Larsen et al. 2009; Moscati 2012; Sundell and Teivainen 2017). However, our detailed empirical comparison shows that even in homogeneous regions, such as Continental Northwestern Europe, national governance reforms that are seemingly inspired by a global reform agenda lead in practice to different, country-specific university governance structures. Consequently, country comparisons are necessary to increase our understanding of the effects of reforms on university governance practices. In this article, we have presented an analytical framework for conducting these country comparisons in a systemic way.

Finally, the move towards more executive and professional university governance has in practice also been affected by specific university traditions and basic institutional features (Olsen 2007). This can 
be illustrated by Huisman et al.'s (2006, p. 238) argument that there “... is little doubt that the Dutch executives have gained a more prominent role in university decision-making, but (...) this does neither mean that 'others' are excluded from the game nor that the 'others' are automatically dissatisfied with the (...) governing structure of the university".

\section{References}

Bleiklie, I. 1998. "Justifying the Evaluative State: New Public Management ideals in higher education." European Journal of Education 33 (3): 299-316.

Carney, S. 2006. “University Governance in Denmark: from democracy to accountability?" European Educational Research Journal 5: 3-4.

Christensen, T., Å. Gornitzka, and P. Maassen. 2014. "Global Pressures and National Cultures: A Nordic University Template?" In University Adaptation at Difficult Economic Times, edited by P. Mattei, 30-52. Oxford: Oxford University Press.

de Boer, H. and B. Stensaker. 2007. "An internal representative system. The democratic vision." In University dynamics and European integration, edited by P. Maassen and J. P. Olsen, 99-118. Dordrecht: Springer.

Enders, J., H. de Boer, and E. Weyer. 2013. "Regulatory autonomy and performance: the reform of higher education revisited." Higher Education 65 (1): 5-23.

Gornitzka, Å. 2020. På letting etter god styring. Et innspil etter invitasjon ("In search of good management. A contribution by invitation"). A paper produced at the invitation of the Norwegian Ministry of Education and Research. See: https://khrono.no/files/2020/02/19/2\%20Gornitzka.pdf (accessed 20 February 2020).

Gornitzka, Å. and P. Maassen. 2014. "Dynamics of Convergence and Divergence. Exploring Accounts of Higher Education Policy Change." In University Adaptation at Difficult Economic Times, edited by P. Mattei, 13-30. Oxford: Oxford University Press.

Gornitzka, Å., P. Maassen, and H. de Boer. 2017. “Change in university governance structures in continental Europe." Higher Education Quarterly 71 (3): 274-289.

Greenwood, R., M. Raynard, F. Kodeih, E.R. Micelotta, and M. Lounsbury. 2017. "Institutional complexity and organizational responses." Academy of Management Annals 5 (1): 317-371.

Hall, P. A. and D. Soskice. 2001. Varieties of capitalism: The institutional foundations of comparative advantage. Oxford: Oxford University Press.

Huisman, J., H. de Boer, and L. Goedegebuure. 2006. "The perception of participation in executive governance structures in Dutch universities." Tertiary Education \& Management 12 (3): 227-239.

Hüther, O. and G. Krücken. 2018. Higher Education in Germany-Recent Developments in an International Perspective. Dordrecht: Springer. 
Krücken, G. and F. Meier. 2006. "Turning the university into an organizational actor." In Globalization and organization: World society and organizational change, edited by G.S. Drori, J.W. Meyer, and H. Hwang, 241-257. Oxford: Oxford University Press.

Larsen, I.M., P. Maassen, and B. Stensaker. 2009. "Four basic dilemmas in university governance reform." Higher Education Management and Policy 21 (3): 1-18.

Maassen, P., E. Moen, and B. Stensaker. 2011. "Reforming higher education in the Netherlands and Norway: the role of the state and national modes of governance." Policy Studies 32 (5): 479- 495

March, J.G., and J.P. Olsen. 1989. Rediscovering institutions: The organizational basis of politics. New York, NY: Free Press.

Moscati, R. 2012. "University governance in changing European systems of higher education". In European higher education at the crossroads, edited by A. Curaj, P. Scott, L. Vlasceanu, and L. Wilson, 599-611. Dordrecht: Springer

Olsen, J. P. 2007. "The Institutional Dynamics of the European University." In University Dynamics and European Integration, edited by P. Maassen and J. P. Olsen, 25-55. Dordrecht: Springer.

Sundell, T. and T. Teivainen. 2017. "Fuzzy Privatization and Decline of Democracy at the University of Helsinki", World economic review 8: 79-92. 